\title{
ASSESSING STATES: WATER SERVICE DELIVERY AND EVOLVING STATE- SOCIETY RELATIONS IN ACCRA, GHANA AND CAPE TOWN, SOUTH AFRICA
}

\section{Leila M. Harris}

Iharris@ires.ubc.ca

University of British Columbia, July 25, 2019

Final version:

Harris, L.M. (2019). Assessing states: Water service delivery and evolving state-society relations in Accra, Ghana and Cape Town, South Africa. Environment and Planning C: Politics and Space. https://doi.org/10.1177/2399654419859365

Citations of this work should use the final version as noted above. 


\section{TABLE OF CONTENTS}

I. Introduction: Approaching states through water services and infrastructures in marginalized sites

II. State of knowledge: shifting state-society relationships, water services and infrastructures, and human right to water

\section{Methods and Research Questions}

IIla. Survey Methods and Key Questions for analysis

IIIb. Study Contexts: Water Access, Governance, and Policy

IV. Results: Reading state-society relations in relation to water services

IVa. State of water access and quality of services in study sites

$\mathrm{IVb}$. Sense of government in relation to water conditions and access

- Trust, interactions, and senses of the government.

- Government Responsibility

- Connecting senses of the state, government, and water services

IVc. Testing trust in government as linked to water access, quality and satisfaction

\section{Discussion}

Va. Country differences

$\mathrm{Vb}$. Varied dimensions of water conditions: ease of access, quality and satisfaction

VI. Conclusion: Key considerations: linking back and moving forward

\section{References}




\section{INTRODUCTION: APPROACHING STATES THROUGH WATER SERVICES AND INFRASTRUCTURES IN MARGINALIZED SITES}

In several recent studies, whether focused on sanitation in Buenos Aires (Morales et al., 2014) water infrastructure in Mexico (Meehan, 2014), or irrigation in Ethiopia (Fantini et al., 2018), a peculiar theme has emerged - relatively impoverished and marginalized citizens respond to questions about water or sanitation infrastructure with commentary on the appropriateness or legitimacy of the 'state.' Meanwhile, academic discussions of the past several decades have largely moved away from narrowly framed state-centered analyses, questioning the very idea of the state as a 'discrete' entity, or as a locus of power. Aiming for greater nuance, recent efforts have sought to attend to diffuse sites and sources of state power, including a growing locus of scholarship on everyday stateness, as well as attention to the 'state' as a field of contested processes and negotiations (Bénit-Gbaffou and Oldfield, 2011). Works that aim to address the 'state' from its margins, through everyday narratives and encounters with marginalized and impoverished citizens provide interesting examples among such works (e.g. Gupta, 1995 for an early intervention along these lines, and Loftus, 2018 for a recent call for more work on the everyday relations important for states from political ecological perspectives). What is striking about these accounts is that speaking about one's daily life, and about things as banal as water or sanitation, residents at once are addressing larger issues related to roles and expectations of government, or what enables citizens to recognize those institutions as trustworthy.

This paper addresses a specific element of these broader issues through a focus on infrastructure and basic services as a key site for negotiation that affects trust in government, state power, or legitimacy. While these linkages are often suggested in the extensive and growing qualitative literatures on political ecologies of states and critical anthropologies of infrastructure (as discussed below), the contribution here adds a multi-sited and multi-method approachincluding specific testing of these linkages to better understand if these connections exist in two distinct country sites, and if they do, how these linkages and connections might be forged. Specifically, we query whether, and how trust in government might be linked by different aspects of water services (access, quality and satisfaction). With these statistical results, the paper then engages with how and why connections and linkages might be forged in particular spaces and times. In so doing, the analysis offers a lens to consider the ways that everyday practices and material infrastructures (notably water services) impinge on trust in government, as one facet of shifting state-society negotiations, and processes of trust and legitimacy as key facets of state consolidation (cf. Sivaramakrishnan, 1999). The analysis relies on a survey conducted in 2012 in marginalized and underserved settlements in two urban African contextsAccra, Ghana and Cape Town, South Africa. By focusing on underserved and marginalized populations and sites - we investigate the state from the 'margins', speaking to a broad set of debates regarding state legitimacy in locales that are distant from state power and influence (cf. Bénit-Gbaffou and Oldfield, 2011, McLoughlin, 2015).

In terms of the results and implications of the work, the contribution here affirms the importance of water politics and infrastructures for state consolidation or legitimacy, and as key foci for explanation regarding power and statecraft in line with several recent contributions (e.g. 
Meehan, 2014, Author and team member, 2016, Carpenter et al., 2012, Meehan and Molden, 2015, Menga and Swyngedouw, 2018). While most other studies that consider these connections are based on qualitative and ethnographic approaches, here we are able to test and analyze these linkages from a mixed-methods and multi-sited approach, including statistical testing, in ways that lend support to these connections while also revealing new insights and nuances. Among other insights, the analysis here highlights key differences both in terms of country contexts, and also various facets of water services. We offer evidence that trust is linked to water quality and satisfaction in South Africa, but not in Ghana, opening up important questions as to why this might be the case. Based on our longer-term research in these contexts, we suggest that these linkages are likely to emerge in relation to geo-institutional and historic specificities, notably policies and discourses related to the human right to water. As such, the analysis also contributes to emergent discussions regarding the human right to water and its implementation, helping to respond to recent calls by Angel and Loftus (2018) to engage more seriously with the state in relation to HRW debates and policies, including what effects this might have for water justice.

After a brief overview of recent research, linked theoretical debates, and contextual considerations related to water access and governance in both study sites, the article turns to the presentation of the findings. Results are based on statistical testing of whether different facets of water services (access, quality, and satisfaction) are correlated with trust in government drawing on a survey implemented across four sites across both urban regions or Accra and Cape Town $(\mathrm{n}=478)$. The discussion moves on to consider key puzzles that emerge from the results including focus on a) the historical and geo-institutional context specificities across both study sites that might account for the observed results; b) considerations as to why trust in government was linked to some aspects of water services (quality and satisfaction), but not others (access); as well as c) what the implications of these results might be for broader debates related to evolving state-society dynamics, the human right to water and its implementation, as well as methodological and conceptual considerations that emerge from these results in relation to broader literatures. 


\section{STATE OF KNOWLEDGE: SHIFTING STATE-SOCIETY RELATIONSHIPS, WATER SERVICES AND INFRASTRUCTURES, AND HUMAN RIGHT TO WATER}

Offering correctives to earlier approaches that treated states as fixed or singular entities, much recent work analyzes the processes and politics that constitute states as ensembles of fragmented institutions or practices. Much work has also focused on how the state-society boundary evolves dynamically (Migdal, 2001), or with it, shifting visions of 'stateness' (Painter, 2006). The approach taken here emerges from this appreciation of everyday states and stateness and allied works on ethnographies of the state (e.g. Gupta, 1995; Author 2012), oriented towards interpreting the state through everyday interactions to highlight the "intense involvement of the state in ordinary aspects of social life" (Painter, 2006). In line with these discussions, political ecologists have also turned increasing attention to the question of the 'state', with a range of recent contributions focused on the ways that nature, resources and infrastructures are central to state and nation building processes (e.g. Menga and Swygedouw 2018, McFarlane and Rutherford, 2008, Whitehead et al, 2007, ). As highlighted in a review essay by Bridge (2014), one of the interesting foci emerging from this work is precisely around how 'states' and 'nature' are generated as 'effects' and what the consequences of these processes are for attendant socionatural relations, including for state power (see also Loftus, 2018). As summarized by Meehan and Molden (2015), political ecology has also been particularly influential in highlighting nonhuman materialities as central to understandings of statecraft and the consolidation of power, whether through water meters as flashpoints of ongoing struggles between states and subjects in South Africa (Loftus, 2006), how residents experience the state through water service delivery in Mumbai and Johannesburg (Bawa, 2011), or the ways that water supply infrastructures (cisterns and buckets) serve both to cement and limit state power in Mexico (Meehan, 2014).

While complex, it is clear from a range of studies of this type that infrastructures and 'natures' are at times central to the consolidation of state power as well as shifting state-society dynamics - a theme that has been increasingly stressed in the growing water focused literature. As Menga and Swyngedouw (2018) assert in a recent volume, water and technological advancement have long been important touchpoints for the consolidation of nation-states (from early work by Wittfogel to recent works inspired by STS or Foucauldian biopolitics, e.g. Hellberg, 2018, Kaika 2006,), noting that "water infrastructure goes beyond control and regulation of water resources, and becomes central in unfolding power dynamics across time and space (2)." Contributions have also touched on the ways that technical expertise and other facets of infrastructures become important for centralized territorial consolidation (e.g. example of Mekorot in Israel, Alatout, 2008), or to fuel nationalism and consolidate state power and senses of loyalty to the state (Fantini 2018 work on dam building in Ethiopia).

Together these works provide us with a heightened appreciation of the ways that water services and infrastructures serve as key sites of negotiation and contestation related to state legitimacy or consolidation (Meehan, 2014, Mosse, 2003). While it is clear that water is not the only domain of such negotiation, and it is clear that other services (housing, sanitation, etc) are also likely important, the mounting evidence focused on water services and infrastructures 
invites us to further query these relationships. Specific to our interests, other studies have compared the ways that improvements in service delivery may foster enhanced trust in governmental institutions, and found that critical services, such as water, have a particularly strong impact on trust (see study by Guerrero 2011 in the barrios in Medellin, Columbia). ${ }^{1}$ Yet, we must not take these linkages to be absolute or given (cf. Menga and Swyngedouw 2018) ${ }^{2}$-as such, it is important to characterize if these linkages exist, and if they do, seek to trace how they emerge and how they might differ and shift across space and over time - all key questions for the present analysis.

While the above examples highlight state-water-infrastructure linkages in diverse historic and geographic contexts, most do so in broad terms drawing on key concepts from governmentality, STS, hegemony, or related discussions. Relatively few studies trace evolving senses of state legitimacy by directly engaging the experiences, narratives, and perspectives of citizen subjects. Among the exceptions, work by Benit-Gbaffou and Oldfield (2011) highlights evolving relationships between low-income residents and the state, focusing on modes of interaction, how these residents represent the state, and changing expectations. Similarly, and specific to water infrastructure, work by Harris focuses on irrigation infrastructure among marginalized residents in the Kurdish dominant border region of southeastern Turkey (2012). Based on interviews, focus groups, and survey responses with these politically and geographically marginalized residents, Harris argues that irrigation infrastructure serves to enhance the legitimacy of the Turkish state - with implications for Turkish state consolidation in a border region where it has long been contested. Previous qualitative work led by Team member and Author (2016) in the context of Khayelitsha, a black township on the outskirts of Cape Town, also focuses on understandings of the state from the perspective of residents in these settlements - revealing that there is a clear division among shack dwellers (who question state legitimacy for not having provided basic services), and among home dwellers who express stronger senses of validation of the state having made good on expectations for basic services. As argued by Benit-Gbaffou and Oldfield, studying the 'entangled geographies of state and society' can be particularly meaningful to better understand ideas of accountability that stand in contrast to Weberian notions of the state as universal, neutral, and based on administrative principles. Rather than through force, coercion, or control, processes of legitimacy and trust are of clear interest as they potentially operate to make residents more or less likely to accept state rule and see particular state agents or institutions as legitimate or competent (with clear links to Gramsican understandings of consent, cf. Sneddon, 2013). All of this begs the key question of the present analysis - do aspects of water infrastructures contribute to senses of trust in government (as one element of legitimacy), and if so, how might we understand the emergence of those linkages and their character in specific times and places?

\footnotetext{
${ }^{1}$ Studies of trust from political science make it clear that trust is a complex phenomenon, with varied and divergent expectations in terms of implications for behavior (such as voting), or compliance (e.g. regulation or taxes) and with diverse theories as to how and whether trust might shift in relation to specific policies (see Levi and Stoker 2000 for definitions and overview, also discussion in Brinkerhoff et al. 2012). While complex, it is clear that trust might be affected by political perspectives, as well as long-term and short-term trends and policy shifts. Trust is also a relational notion that is linked with capacity that must be maintained.

${ }^{2}$ As Menga and Swyngedouw (2018) write: "hydraulic infrastructures thus emerge as one of the ways in which the state actualises power over its territory, and therefore, also as one of the ways in which power can be contested."(4)
} 
While quite distinct in terms of theoretical engagement and conceptual frameworks, it is important to note the ways that similar issues have been taken up in political science, planning, and development policy fields - including several works that focus on the services-trust interface. Among them, Migdal (2001) has conceptualized goods and services as part of a "package of rewards, sanctions and symbols that that state ultimately provides in order to achieve social control". The OECD (2011) has also suggested that basic services "play a major role in enhancing state legitimacy" (both discussed in McLouglin, 2015), while others have analyzed the specific pathways whereby basic service delivery serves to consolidate state legitimacy in fragile and conflict-affected states (Brinkerhoff et al., 2012). As these authors suggest, effective public goods ands services are important for public participation and accountability, yet, the "specifics of how security, service delivery and political participatory and accountability contribute to state legitimacy are not well understood (Brinkerhoff et al., 2012: 274)." Detailing interrelated factors that have been shown to be critical sources of state legitimacy, they highlight: effective provision of public goods and services provided a levels of quality, quantity and equity satisfactory to citizens; political participation and accountability with responsive and accountable government; representation and inclusiveness; as well as security to protect people and property.

While not necessarily a widely shared view in state theory, Carpenter, Slater and Mallet (2012) similarly conclude that the idea of a causal link between service delivery and state legitimacy has nonetheless "achieved the status of received wisdom in aid policy." In a summary of service delivery performance across 34 African countries, Asunka (2013) similarly notes that ease of access to basic services plays an important role in citizen assessments of government performance, while Levi et al. (2009) analyze Afrobarometer surveys and find that service performance contributes to legitimacy and trust in state authority in multiple African contexts. ${ }^{3}$ A World Bank report authored by Guerrero (2011) similarly adds quantitative evidence from Medellin Columbia, and asserts, among other findings, that perceptions of improved service delivery and satisfaction with services are potential channels to counter long-held patterns of distrust in government, serving to rebuild trust in institutions. McLoughlin (2015) provides a critical summary of this range of discussions related to ways that service delivery might affect legitimacy of states, including focus on trust as a proxy (e.g. example by Rothstein, 2009 from the U.S. suggesting that impartial service delivery was positively associated with higher trust in government), providing a foundation to set up the work endeavored here. Learning from the body of evidence, McLoughlin (2015) suggests that there is clear evidence that infrastructures can serve to foster legitimacy and trust in the state, but evidence from multiple case studies makes it clear that these relationships are non-linear. As such, there is a need for a "more rounded accounts of the significance of service delivery for state legitimacy," including looking "beyond the material to include attention to the ideational and relational significance of services, and the normative criteria by which citizens judge them" (McLoughlin, 2015:341).

Before proceeding to the results and discussion, it is important to provide a brief summary or recent discussions related to the human right to water and its uneven implementation. Following its adoption by the United Nations General Assembly in 2010, as well as its inclusion

\footnotetext{
3 As these authors assert, in the initial stages services are critical to establish the government's trustworthiness. Following this, citizens increasingly have a sense of obligation and willingness to obey state authority, resulting in enhanced compliance with state rules (e.g. payment of taxes, respecting laws, etc...)
} 
in a number of national policy frameworks, a growing literature interrogates the significance of the human right to water as a policy discourse and set of practices (e.g. Sultana and Loftus, 2012). There is also considerable interest in its uneven implementation across sites (Mehta, 2006). As Angel and Loftus (2018) note, a number of interesting questions arise specifically at the intersection of the human right to water, associated water justice struggles and political ecologies of the state. Notably, they raise concerns related to the potential for human right to water and similar discourses to reify the state, and with it, the possibility that other more radical routes to water justice may not be pursued. For instance, focus on state provision of services potentially centers attention on access and basic needs, and the state as 'legitimate' as a purveyor of these services, potentially leaving aside more radical political economic questions related to root causes and dynamics that leave some communities particularly vulnerable in terms of access, affordability, or water quality. ${ }^{4}$ Thus, while some theorists suggest that a recentering of the state may be particularly needed to achieve the HRW, particularly to counter neoliberalization trends (e.g. Mirosa and Harris, 2012), or to recenter the 'public' in public services (work of the Municipal Services Project, 2018), Angel and Loftus (2018) strike a note of caution, suggesting we instead work 'with against and beyond the state' and to remain attentive to those spaces, politics and radical possibilities that might be foreclosed with state-centric discourses and policies. Our project fits well within their call to focus greater analytical attention to the question of the state in relation to the human right to water-we return to these concerns following the presentation of data related to the state-trust-water services nexus in our study contexts. The next section (III) provides details on methods as well as contextual elaboration of water access and governance in both study sites, before turning to our results (Section IV), followed by the discussion (Section V) and Conclusion (Section VI).

\footnotetext{
${ }^{4}$ For instance, work by Bustamante and colleagues (2012) working in Bolivia suggests that a focus on the state, and state provision of services means that other organization and institutional forms may not be recognized, raising concerns for water justice struggles.
} 


\section{METHODS AND RESEARCH QUESTIONS}

\section{IIlla. Survey Methods and Key Questions for Analysis}

This study is one part of a broader multi-year, multi-sited research project ${ }^{5}$ focused on water access and governance in underserved sites in several urban African contexts. South Africa and Ghana are both countries of particular interested related to uneven conditions of water access and governance, for instance, with the constitutional right to water and a suite of policies such as the free basic water policy in South Africa, while Ghana was the site of intense struggle related to the privatization of water services as part of World Bank conditionalities, leading to resistance that highlighted the ways that these shifts might be particularly detrimental for impoverished residents (discussed below). The analysis here relies on a 2012 survey conducted in two sites of Accra (Ashaiman and Teshie), and two sites of Cape Town (Khayelitsha and Philippi). All the sites were selected as examples of relatively impoverished and underserved sites, ${ }^{6}$ for a total of 478 households (254 respondents in South Africa and 239 in Ghana). ${ }^{7}$ Again, a key focus for the study overall is to document and understand how vulnerable and impoverished locations and populations might be affected by water governance shifts and policies, a concern that is also of particular interest for the issue of state consolidation and state-society dynamics (as noted above). The surveys were carried in out in collaboration with local partners and were conducted in local languages with direct translation to English by the multilingual interviewers (surveys were mostly conducted in Xhosa and Afrikaans in Cape Town and Twi and Ga in Accra, although some were undertaken in English depending on the fluency and preference of the respondent).

Through statistical analysis, we answer the following:

1. Is trust in government correlated with ease of water access, perceived quality, or satisfaction with services? ${ }^{8}$

In the discussion and conclusion, we read these results in relation to two linked questions:

2. How do the results vary across our two case study locales of Accra and Cape Town, and what does this suggest in terms of the character of these linkages as mediated by key aspects of socio-political, and historical context?

3. What might these linkages suggest in terms of broader debates of interest, including evolving state-society relations, or the human right to water and its implementation?

\footnotetext{
${ }^{5}$ See edges.ubc.ca for details (http://edges.sites.olt.ubc.ca/research/edges-comparative-water-governance-in-africaresearch-project-cwgar/)

${ }^{6}$ Although the sites might reasonably described as 'slums' consistent with the United Nations' definition, we prefer the term 'underserved.' 'Informal' is not accurate given that there is formal ownership and recognized rights of occupancy in these sites.

7 The sample size may vary based on the number that actually responded to each specific question.

${ }^{8}$ Although sanitation is an important concern in all sites, and is linked to the issues discussed, our survey and results focused on domestic water provision.
} 
Before proceeding, it is worth reiterating that while the survey results are at times presented using the language of 'South African and Ghanaian respondents,' the reporting is only for our specific research sites. We are also cognizant of the fact that reporting the results in a comparative fashion at times may be unhelpful, for instance, with a sense that the relatively strong numbers related to service quality and access in South Africa might serve to depoliticize what is clearly an important and contentious issue (see discussion below on service delivery protests, per Alexander, 2010, Thompson, et al., 2011). Nonetheless, we find that analyzing the data together and separately by country is helpful precisely to consider how state-society linkages might be differently forged in various sites. As such, we are not aiming to compare these distinct sites, but instead use key differences as an opening to thinking through the specific histories, politics and concerns related to water access, quality and services. The discussion is focused precisely on these specificities, particularly in South Africa where the results are more robust. To help move towards this specificity, the following sections provide further details on water governance and other policy considerations in both study contexts.

\section{IIlla. Study Contexts: Water Access, Governance, and Policy}

Accra and Cape Town differ considerably with respect to water access and governance. ${ }^{9}$ In Accra the entity responsible for urban water provision is a national entity the Ghana Water Company Limited (GWCL), which retook control from the private AVRL (Aqua Vitens Rand Limited) consortium in 2011 after a five-year contract to manage the urban water system. According the GWCL approximately half of the residents of metropolitan Accra have access to piped water, but the numbers are considerably less in the underserved neighborhoods including those targeted for our survey (Teshie and Ashaiman). Among our survey respondents, we found that $47 \%$ of residents primarily accessed water through vendors, and closer to $24 \%$ of respondents obtained water through the piped network (i.e. in-house tap or private water tank). Even those with access to piped service enjoy only intermittent service due to leaks as well as long-term reliance on a rationing schedule ${ }^{10}$ (well-off residents rely on storage and it is common for residents draw on multiple water sources, see Peloso and Morinville, 2014). Affordability, conflict, and worry are also significant water related challenges reported by our survey respondents (see also Dapaah and Harris 2017). Of interest for the human right to water, it is notable that there is no specific language related to human rights in Ghanaian legislation and policy frameworks - an issue that NGOs based in Accra are working to remedy (Yates and Harris, 2018).

In South Africa, there are several policies relevant to the water sector, including the human right to water and sanitation in the national constitution, as well as the Free Basic Water policy. The responsibility for implementation and water service delivery rests with municipal

\footnotetext{
${ }^{9}$ See also Bond and Dugard, 2008 for South Africa, or work by Ainuson, 2010, Stoler et al., 2012, Yeboah, 2006 for Ghana, in addition to the linked projects of our own research team (e.g. Peloso and Morinville, 2014; Rodina, 2016, Yates and Harris, 2018). Summary policy documents for each locale also available on our project website: www.edges.ubc.ca

10 Interviews with GWCL officials in 2015 suggested that the rationing schedule is no longer necessarily due to an augmentation in the system supply with a new desalination plant.
} 
governments, leading to variable implementation and success of these programs across the country. There have also been several high profile and influential court cases where residents have pushed the government in terms of failure to realize its constitutional obligations-leading to some reformulation of related water policies across the country, as well as substantial critique in terms of the failure of South Africa to achieve on-the-ground improvements for marginalized residents (Bond 2012). Critics have also frequently emphasized the mis-match and nonprogressive tendencies of neoliberal and commodification policies that are often pursued in tandem with HRW efforts-raising concerns about what this means about water justice and progressive realization of the HRW (Bond 2012 Clark 2017, McDonald and Ruiters 2005). For instance, recent work has emphasized the ways that the idea of the Human Right to water, pursued through the free basic water policy, has resulted in fundamental tensions and difficulties for relatively impoverished households - particularly through Water Demand Management Devices (WDMs) which has become a primary instrument to achieve these goals, in ways that have resulted in cut-offs, political contestation, and undue burden for poorer households (Yates and Harris, 2018, Wilson and Pereira, 2012). The devices have been contested in part because they have until recently disproportionately targeted poor households, and are often forced in the context of debt management, a pattern that is only recently shifting with the extension of the devices into wealthier neighborhoods with recent drought management efforts (ibid). Nonetheless, official statistics related to water services in Cape Town also make it clear that there have been considerable investments and some notable successes in terms of water service coverage in impoverished settlements (e.g. an estimated $97 \%$ of residents in the Western Cape enjoying access to improved water ${ }^{11}$ within 200 meters of the home, CCT, 2012). Nonetheless, the issue of service delivery remains hotly contested, and is frequently challenged (e.g. see citations above, also Smith and Hanson 2003). Among other possibilities, while 'access' might be available, affordability and other considerations do not always translate into water security, particularly given cost recovery and similar policies (CCT, 2012). As such, many activists are pushing for issues of dignity, respect, free prior and informed consent related to WMDs, as well as issues of continuous water flows to counter the cut offs and specific experiences as these technologies and policies are experienced unevenly across settlements in Cape Town and surrounding areas.

Among our survey respondents in Philippi and Khayelitsha (among the most underserved areas in the region, both black township settlements), 59\% suggested that have an in house or inyard connection, and all others access water through communal taps. Even as communal taps are compliant with Joint Monitoring Program (JMP) definitions of safe access, there are a number of social and political issues associated with this mode of access, from senses that the water is less safe, and less hygienic (or otherwise suboptimal relative to private in-home taps as well as the broader standard for those living in other parts of Cape Town (team member, 2016). Again, progress made towards realization of the right to water does not mean that these issues are not strongly contested - indeed, there has been an uptick of 'service delivery protests' over the past

\footnotetext{
11 Definitions of 'improved water access' from the Joint Monitoring Program (WHO \& UNICEF, 2008) include any water source that is considered to be less subject to contamination, notably fecal contamination, including rainwater, boreholes, or centralized service delivery, although critics have offered alternative definitions and have suggested that 'improved water' may be unsafe and may not confer expected health benefits (Mahama et al., 2014)
} 
decade highlighting water and sanitation services across the country, including in the Western Cape (Alexander, 2010, Thompson et al., 2011).

Our interest in conducting work in the two urban sites of Accra and Cape Town was motivated by an interest in understanding the uneven implementation of diverse water governance practices, with focus on implications for impoverished and marginalized populations. For instance, neoliberalized water governance practices including privatization, commodification, and marketization had been increasingly pushed the International Financial Institutions (IFIs), are often met with resistance in the name of marginalized and vulnerable populations (AmengaEtego and Grusky 2005 detail the resistance to privatization of Accra's water system; while others have documented the effects of ongoing commodification and neoliberalization on impoverished and marginalized populations in South Africa, e.g. McDonald and Smith, 2004; McDonald and Ruiters, 2005). Our overarching project considers the implications of these conjoined policies (e.g. HRW and neoliberalization shifts), from a lived experience perspective in among impoverished and marginalized residents. The focus on shifting state-society relations is one dimension of changing experiences and expectations of water access, and conditions and meanings within the context of this broader study (see website for details). 


\section{RESULTS: READING STATE-SOCIETY RELATIONS IN RELATION TO WATER SERVICES}

The results are organized into three sub-sections. First, section IVa provides further data from the survey on water access and governance in our study sites. Second, section IVb analyzes survey responses relevant for understandings of government and the state, including senses of governmental responsibility for service provision. Third, section IVc provides results of statistical tests querying whether sense of trust in government correlates with responses regarding water-related access, quality and satisfaction. Following reporting of results, the discussion section moves on to engage with broader insights from political ecology understandings to uncover key aspects of political economic, institutional and historic context that might help us to explain these, as well as to uncover why different aspects of water might be linked to 'trust' in government in different ways. The conclusion then broadens to consider implications of the study for state-society dynamics, as well as debates regarding to the human right to water and its implementation.

\section{IVa. State of water access and quality of services in study sites}

South African respondents were more likely that their Ghanaian counterparts to agree that water was easy to access, of good quality, and that they were satisfied with water services (Figure 1). Specifically, a clear majority of our South African respondents felt that water was easily accessible (83\%) and of good quality (92\%). While a majority of South African respondents also reported satisfaction with water services $(64 \%)$, this is considerably lower than the other indicators - suggesting that other factors apart from access and quality are being taken into account.

In Ghana respondents were much more positive about water quality as compared with water access (58\% agree or strongly agreed that water was of good quality, while only $28 \%$ agreed or strongly agreed that water was easy to access). ${ }^{12}$ Other notable features about the situation in Accra relate to the high reliance on vendors (nearly half of respondents), considerable reporting of conflict associated with water access in communities, and relatively low rates of satisfaction with water services $(27 \%)$. Speaking to the social-psychological aspects of access, $49 \%$ of South African respondents say they 'never worry' about water in comparison with the same percentage in Ghana who respond that they 'often worry' (cf. Wutich and Ragsdale, 2008 on stress linked with daily water related transactions).

\footnotetext{
12 See Peloso and Morinville, 2014 for more details on the myriad of access strategies that one might deploy to secure water access in Ashaiman, Ghana, Dapaah and Harris, 2017 for discussion of access and entitlements in the communities of Ga Mashie and Madina, Ainuson, 2010 for overview for Accra generally, or Rodina, 2013 for qualitative analysis on water access and governance in Site C, Khayelitsha.
} 
Figure 1: A comparison of Likert responses to three questions in Ghana and South Africa

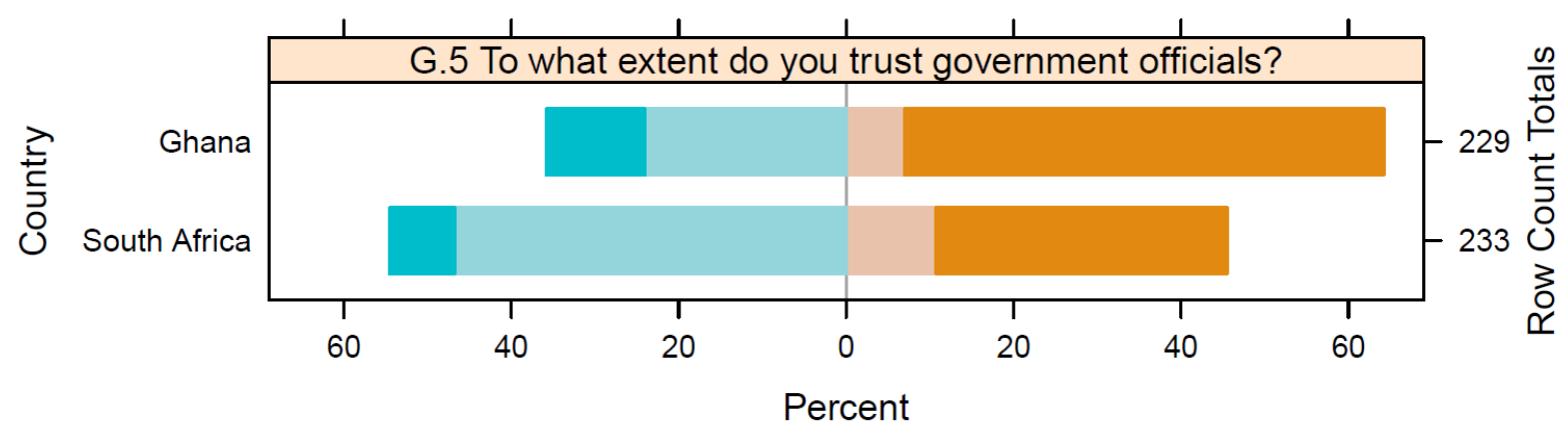

Trust.them.fully

Somewhat.trust.them

Somewhat.do.not.trust.them

Do.not.trust.them

\section{Modified Likert Scale}

\section{IVb. Sense of government in relation to water conditions and access}

Trust, interactions, and senses of the government.

Overall, we see trust in government in South Africa (55\%), is higher than the figures for Ghana (36\%; Figure 2). ${ }^{\mathbf{1 3}}$ It is also notable that there is a substantial subset of respondents in both countries who answered that they do not trust fully.' We also observe higher levels of trust in NGOs, and higher trust of others in the community among South African respondents.

In highlighting senses of government, it is important to note that in some of these questions, and responses, the scale of government referred to is ambiguous. Several questions asked did distinguish between municipal and national scales of government. However, we did not observe clear differences in responses to these questions. As such, it appears that the various scales of government were insufficiently clear, or not sufficiently teased out, as part of the survey design. For Accra, arguably the scale ambiguity is not as important, given that the GWCL provides water for urban areas across the country.

To understand how people interacted with their government over water related issues we also asked if respondents had ever been contacted by their government about issues related to water, or if they would contact their local government with a water-related problem. Forty-one percent of the South African respondents had been contacted by a government official regarding water compared with $12 \%$ in Ghana. Relatedly, $87 \%$ of respondents in South Africa said they would go to a local councilor with a water-related problem, a response that was much lower in Ghana at 26\%. In Ghana, the responses to this question were much more diffuse among options

\footnotetext{
13 Afrobarometer data suggests that trust in both South Africa and Ghana is declining since 2011. In Ghana, the majority of residents have little or no trust in government institutions. In South Africa, corruption scandals associated with Zuma, with culmination with the 'state capture report' released in November of 2016 (TimesLIVE, 2016) and other factors are responsible for a precipitous decline in trust in government institutions over the past several years (Afrobarometer, 2016; Chingwete, 2016).
} 
(many said they would 'go to a fried' or 'do nothing'), demonstrating the lack of a clear pathway for people to seek support on water-related problems. The ability to rely on local councilors in South Africa suggests that at some level there might be greater trust, or senses of legitimacy in the local governance system. This however does not negate the significant work on local governance in South Africa that suggests considerable gaps and need for reform (see work by Piper and colleagues for extensive analysis of local government dynamics in the South African context, e.g. Piper and von Lieres, 2015).

Figure 2: A comparison of Likert responses to government trust in Ghana and South Africa

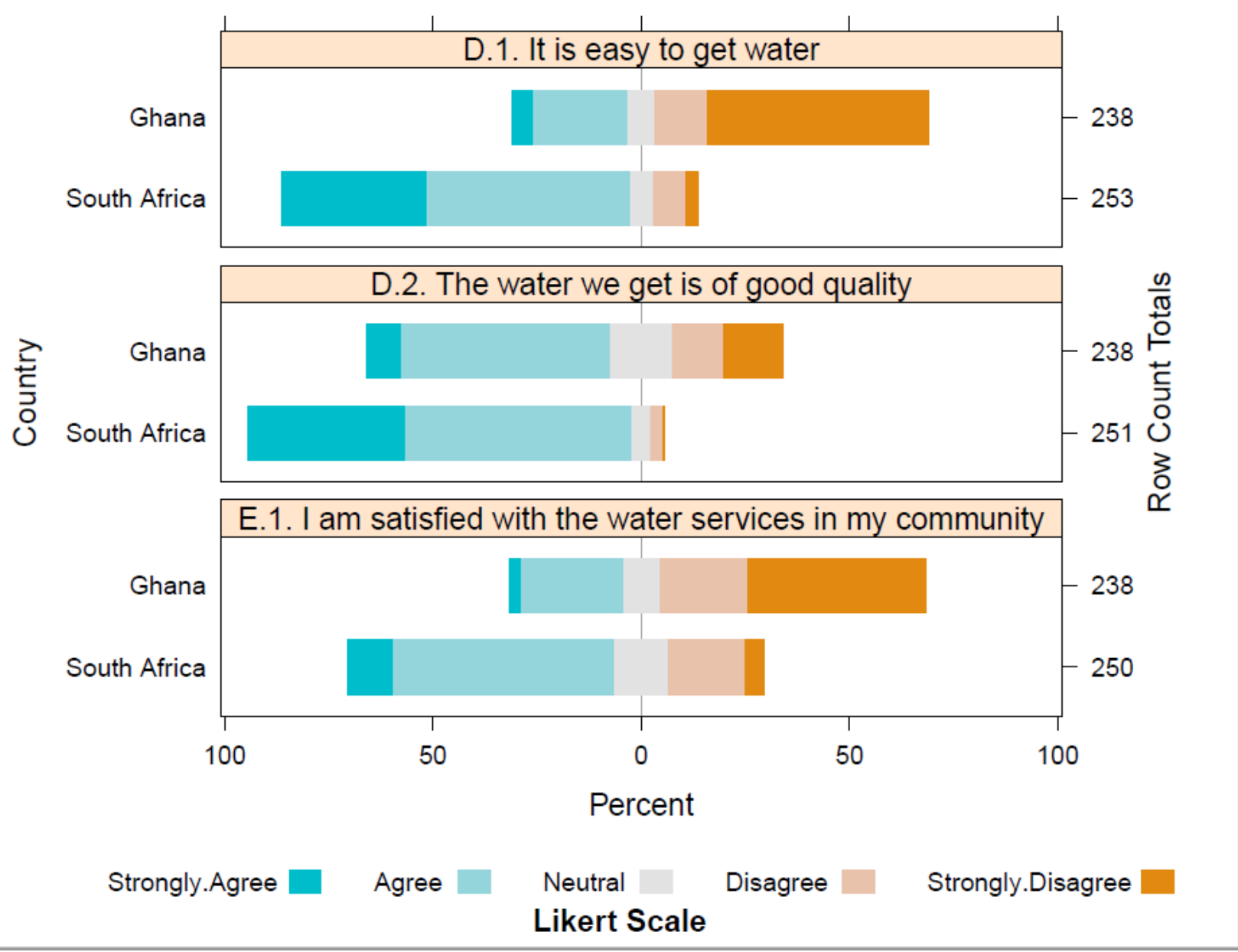

It is also worth noting that even as a slight majority of respondents in South Africa suggest that they trust the government, there is still over $40 \%$ who replied that they do not trust the government (there were higher senses of distrust among the Ghanaian respondents, over $60 \%$ ) and considerable proportions in both countries selected the most negative response- 'fully do not trust.' The degrees of distrust are important to note, particularly given clear signs of discontent and indicators of disenfranchisement in both countries. Consider that among a list of possible community concerns (with the preface: what are the most serious concerns in your 
community?), $42 \%$ in Ghana and $61 \%$ in South Africa agreed with the statement: 'we feel that no one cares about us.' Here we see an interesting tension, explored more fully in the discussion, that while many of the indicators of water and or even trust in government appear to be fairly positive (notably in South Africa), there is nonetheless an undeniable current of disenfranchisement. The sense of discontent in South Africa is again bolstered by the significant service delivery protests, an issue frequently mentioned in the literature and by the press (Nleya, 2011, , Redfield and Robins, 2016, Roberts et al., 2018).

\section{Government Responsibility}

As a reminder, in Ghana, the entity responsible for urban water provision is the national entity, the GWCL. In South Africa, responsibility falls primarily on municipalities. As well, the majority also felt the government should expend much more effort for water provision. A strong majority of respondents in both countries agree or strongly agree with the statement: 'I think the government should put more effort into providing water for my community' ( $95 \%$ in Ghana and $67 \%$ in South Africa).

\section{Connecting senses of the state, government, and water services}

The above data from the survey variously suggests that ways that respondents felt about the government, for instance, reporting on senses of trust, and also the sense that for many water provision is that the responsibility of government, and government should be doing more. We also asked directly if respondents feel differently about their governments when water is readily available. In response, $29 \%$ of Ghanaian respondents agreed that they felt differently towards their government when water was available, in contrast to the $55 \%$ of South Africans that reported feeling proud of their government because of 'they are always able to access water.' These responses were again similar for questions asked specific to local and national governments (in ways that were not anticipated and likely suggest a weakness in the survey design given that there was not a more clear difference observed between these levels of government). ${ }^{14}$

As we might anticipate, when we look at the open ended follow up questions related to this relationship, many clearly suggested that they feel more positive towards government when their water services or access is better. However, analysis of the follow on question "why did you respond the way you did," also reveals that people read this question very differently, with a number of respondents suggesting that their opinion of government doesn't change when water access improves "because the government is still not doing enough," or "I feel it is their duty to supply so I rarely feel differently," and so forth. For instance, one Ghanaian respondent noted, "the national government and district are not living up to expectations. I feel disappointed and dispirited." Thus, it seems that some do feel differently, and indeed more positively towards the government when water services improve, but others remain dispirited or feeling as though still

\footnotetext{
${ }^{14}$ We would have especially expected this in the context of Cape Town, where the municipality is run by the opposition party, the Democratic Alliance, while the national government has been run by the ruling African National Congress party (ANC) since democratization. Further to this, it is know that the black townships where our survey was undertaken are ANC strongholds - as such, there should be more to distinguish responses related to municipal and national governments - an issue important to investigate further in follow up work.
} 
more needs to be done-minor improvements in water services are simply not enough to alter the overarching sentiments and senses of government or trust. This possibility is reinforced by the overwhelming percentage of respondents (in both countries) that suggested that the government should be doing more related to water provision (per above), in addition to the strong subset who suggest that they 'do not fully trust' government (Figure 2).

\section{IVc. Testing trust in government as linked to water access, quality and satisfaction}

Turning to our statistical tests, we hypothesized that if there is a connection between water and trust in government we should expect that among those that agree that they have easy access to water, good quality water, and are satisfied with water services, a greater percentage should trust the government. Conversely among those that do not feel they have easy access to water, good quality water, or are satisfied with water services, we would expect a greater proportion to distrust the government. We created two by two frequency tables and used a chi square $\left(\chi^{2}\right)$ test for statistical significance (Table 1$)$.

In Ghana there was no significant connection between water and trust in government for any of the three measures (Table 1). For South Africa, the linkage between water quality and water satisfaction with trust in government was as expected and significant (Table 1).

When we compare these results to those of the directly asked question, there are some elements worth noting. For example, a much greater proportion of South Africans stated that their access to water would change their feelings towards their government (55\% of South Africans compared to $29 \%$ of Ghanaians). The ambiguity of Ghanaian respondents to the direct question is reinforced by the lack of significant patterns in the statistical test. Another important thing to note is that ease of access to water was not significant in either study site. Recall that for the direct question asked (as discussed in section $\mathrm{Vb}$, above), access was the word that was used. This suggests that if we had asked directly about quality or other dimensions, the answers could have been different. 
Table 1. Fisher exact test of contingency tables of water and governance responses

\begin{tabular}{|c|c|c|c|c|c|c|c|c|}
\hline \multirow[b]{2}{*}{ Country } & \multirow[b]{2}{*}{ Water question } & \multirow[b]{2}{*}{ Response } & \multicolumn{3}{|c|}{$\begin{array}{l}\text { G.5. To what extent do } \\
\text { you trust government } \\
\text { officials? }\end{array}$} & \multicolumn{3}{|c|}{$\chi^{2}$ test $(d f=1)$} \\
\hline & & & Trust & $\begin{array}{c}\text { Do not } \\
\text { trust }\end{array}$ & $\mathbf{n}$ & $\chi^{2}$ & $\begin{array}{l}\text { p- } \\
\text { value }\end{array}$ & $\underset{\text { total }}{n}$ \\
\hline \multirow[b]{2}{*}{ Ghana } & \multirow[b]{2}{*}{ D.1 It is easy to get water } & Agree & $46 \%$ & $54 \%$ & 27 & \multirow[b]{2}{*}{3.201} & \multirow[b]{2}{*}{0.074} & \multirow[b]{2}{*}{213} \\
\hline & & Disagree & $32 \%$ & $68 \%$ & 166 & & & \\
\hline \multirow{2}{*}{ Ghana } & \multirow{2}{*}{ D.2 Water is of good quality } & Agree & $39 \%$ & $61 \%$ & 132 & \multirow{2}{*}{0.388} & \multirow{2}{*}{0.533} & \multirow{2}{*}{193} \\
\hline & & Disagree & $33 \%$ & $67 \%$ & 61 & & & \\
\hline \multirow{2}{*}{ Ghana } & \multirow{2}{*}{ E.1 I am satisfied with water services } & Agree & $43 \%$ & $57 \%$ & 61 & \multirow{2}{*}{1.460} & \multirow{2}{*}{0.227} & \multirow{2}{*}{208} \\
\hline & & Disagree & $33 \%$ & $67 \%$ & 147 & & & \\
\hline \multirow[b]{2}{*}{ South Africa } & \multirow[b]{2}{*}{ D.1 It is easy to get water } & Agree & $53 \%$ & $47 \%$ & 193 & \multirow[b]{2}{*}{0.001} & \multirow[b]{2}{*}{0.976} & \multirow[b]{2}{*}{218} \\
\hline & & Disagree & $56 \%$ & $44 \%$ & 25 & & & \\
\hline \multirow{2}{*}{$\begin{array}{l}\text { South } \\
\text { Africa }\end{array}$} & \multirow{2}{*}{ D.2 Water is of good quality } & Agree & $56 \%$ & $44 \%$ & 212 & \multirow{2}{*}{4.176} & \multirow{2}{*}{0.041} & \multirow{2}{*}{220} \\
\hline & & Disagree & $13 \%$ & $88 \%$ & 8 & & & \\
\hline \multirow{2}{*}{$\begin{array}{l}\text { South } \\
\text { Africa }\end{array}$} & \multirow{2}{*}{ E.1 I am satisfied with water services } & Agree & $60 \%$ & $40 \%$ & 146 & \multirow{2}{*}{4.311} & \multirow{2}{*}{$\mathbf{0 . 0 3 8}$} & \multirow{2}{*}{198} \\
\hline & & Disagree & $42 \%$ & $\mathbf{5 8 \%}$ & 52 & & & \\
\hline
\end{tabular}

"Neutral", "I Don't Know", and "Wish not to say" responses were removed from this analysis. "Strongly Agree" and "Agree" were coded as "Agree". "Strongly Disagree" and "Disagree" were coded as "Disagree." "Fully trust them [government]" and "Somewhat trust them" were coded as "Trust". "Do not trust them [government]" and "Somewhat do not trust them" were coded as "Do not trust." Significant results are highlighted above in bold. 


\section{DISCUSSION}

To recap, for South Africa - but not in Ghana -satisfaction with water services, and reports of better quality of water, correlate with increased trust in government. This adds statistical support to the broader suggestion in the literature that resource access, services, and infrastructure may be linked to state legitimacy or power-connections that have mostly been highlighted qualitatively and conceptually to date (e.g. Meehan, 2015; McLoughlin, 2015). However, it is worth asking: Why are the correlations between water conditions and trust in government positive and statistically significant in our South Africa sites, but not in Ghana? Why are water quality and satisfaction linked to trust in government (in South Africa), but not ease of access? After considering these questions in relation to institutional, political-economic and historic considerations, the conclusion addresses the implications of these results for debates related to shifting state-society negotiations as well as of the human right to water and its uneven implementation. The discussion focuses on South Africa where results were significant and robust.

\section{Va. Country differences}

One clear puzzle that emerges from the analysis relates to the country differences. The answer is fairly straightforward but also very interesting. What we are observing is that there is no necessary and 'given' relationship between service infrastructures as a site of political negotiation around trust in government or state legitimacy — rather these connections are forged iteratively through institutions, discourses, legal frameworks, policy pathways, and state practices. This result aligns with McLouglin's (2015) response to the 'received wisdom' that provision of vital public services necessarily improves the legitimacy of states. As she writes "the relationship between a state's performance in delivery services and its degree of legitimacy is non-linear. Specifically this relationship is conditioned by expectations of what the state should provide, subjective assessment of impartiality and distributive justice, the relational aspects of provision... and characteristics of the service (347)" This points to the factors and discourses that over time have fostered a tight coupling of services and state legitimacy in South Africa, in a way that does not appear to hold in Ghana.

In South Africa, it is fairly easy to trace the clear linkage between water (and sanitation) services and senses of the state, including state legitimacy or authority. With the coming to power of the ANC as the first democratically elected government in the 1990s, there were explicit promises made related to basic service delivery as a component of redress for past injustices of colonial and apartheid periods. The focus on equitable service delivery and redress was affirmed by the 1996 constitution — which includes the goals of equitable service delivery (for water, electricity, and sanitation), as key symbolic and material means to realize a more equitable and democratic South Africa (Sahle et al, 2019). Constitutional language (1996) asserts that "everyone has the right to access sufficient food and water" (Section 27b). Sub- section (2) adds that "[t]he state must take reasonable legislative and other measures, within its available resources, to achieve the progressive realization of each of these rights" (RSA, 1996). It is precisely a consequence of these policies, and their associated politico-discursive mappings, that 
"democracy, rights, and citizenship in South Africa have become tightly tethered to popular demands for access to state services, technologies and infrastructure" (Redfield and Robins, 2016:145, cf. Angel and Loftus, 2018). ${ }^{15}$

For Ghana, there is little in the way of comparable discourse or policy frameworks that couple the idea of the state to water infrastructure and services. This is something that NGOs, including Accra-based ISODEC, are aiming to change with an ongoing push to adopt a legislative framework around the human right to water and sanitation-a move that would likely foreground senses of 'rights' to water among the citizenry, and with it enhanced senses of state responsibility (cf. Collaborator and Author, 2018). However, as our results suggest, this coupling of state responsibility and services is not yet in evidence. In our qualitative work as well, which included interviews and focus groups over multiple years in various neighborhoods of Accra, we find little by way of narrative among citizens that directly connects the state to service delivery. Apart from the lack of an explicit policy framework around the human right to water, the fact that water access if often mediated by vendors and intermediaries (and not always directly with the GWCL), and also that Accra's system was managed by a private consortium between 20062011 are factors that might serve to delink government responsibility, trust, and service quality and satisfaction.

\section{Vb. Varied dimensions of water conditions: ease of access, quality and satisfaction}

With respect to an understanding of the puzzle that emerges as to why trust in government in South Africa is linked to water quality and satisfaction, but not ease of access, other considerations that are useful to highlight. Specifically, recall that while respondents in townships of Khayelitsha and Philippi generally respond very positively concerning ease of access ( $83 \%$ agree that water is easy to access) and quality (92\% agree that water is of high quality), there is a considerable drop when asked about satisfaction (closer to 64\%). Importantly, the legal and discursive framework in South Africa related to the right to water (and sanitation) is not merely about providing everyone with basic access, but rather there is emphasis on the idea that services should be equitable, and that achieving this goal is a cornerstone to realize the goals of an equitable and democratic South Africa. It is of interest that language of the Water Allocation Reform Strategy (WARS) of 2008 asserts the centrality of equity for future water policy, asserting that by 2024 " $60 \%$ of allocable water should be in the hands of black people of which half should be in black women's hands" (DWAF, 2008, see also Miraftab, 2007). With respect to the results, this gives us clarity with respect to the fact that while basic access has largely been achieved (recall it is above $90 \%$ in these areas for basic access figures); the focus for many is on whether the quality of water is comparable relative to other communities (in other words, satisfaction as well as linked notions of equity are more significant for trust). As long as there are marked inequities between water services in the townships (e.g. shared standpipes,

\footnotetext{
15 It is interesting to note that citizens' expectations often shift as different goals are achieved. Work by Guerrero 2011 in Medellin, Columbia found that trust increases with improved service delivery in barrios, but that there are diminishing returns as citizens perceive less improvements after a certain threshold — ie., additional improvements are viewed as less significant.
} 
broken infrastructure, water cut-offs), and what one enjoys in the nearby suburbs, the gap between water quality, access, and 'satisfaction' will remain (McDonald, 2008). Again, this is consistent with other studies, including work by Guerrero in Columbia, that suggests that perceptions of improvements for services (progress), as well as notions of procedural or administrative fairness, are more significant that the actual quality of the services themselves. While basic access is nearly secure, equity and fairness are more likely at the root of ongoing dissatisfaction among residents in South Africa. ${ }^{16}$

This backdrop also helps us to make sense of the fact that while many of the indicators of water access and quality appear to be very positive in South Africa (whether from official statistics, or from our survey results which largely track against other surveys conducted in townships around Cape Town), ${ }^{17}$ this does not discount, or minimize the very real senses of disenfranchisement or strong feelings that the government should be doing more. Again, several of our survey results provide strong hints of these sentiments: many in Khayelitsha and Philippi reported that they wish they could participate more in water related discussions, and a majority (61\%) agreed with the statement that they 'feel that no one cares about them.' As well, the ongoing service delivery protests speak volumes to the idea that residents are not satisfied with the state of services, and that relative inequity is an important dimension of these grievances whether for water, sanitation, or housing (Alexander 2010). Indeed, while all of these services are important to the politics of the state and legitimacy in South Africa, at times water serves as a particularly strong emblem for equity concerns - particularly as domestic water is seen as so basic and fundamental to human well being, as well as broader understandings of dignity, cleanliness, and so forth. In the more recent several years (after our survey was conducted) data suggests that satisfaction with basic services is on the decline across South Africa-approval of water and sanitation delivery fell from $86 \%$ in 2016 to $61 \%$ in 2017 (Roberts et al., 2018). Also of interest for our analysis, recent data from the South African social attitudes survey suggests that confidence in local government in the Western Cape is falling during the same time period, from 57 to $44 \%$ (likely linked to corruption scandals, growing dissatisfaction with the government, or the recent mismanagement of the drought in the Western Cape, among other possible factors, Roberts et al., 2018)

Considering the different results observed in underserved areas of Accra and Cape Town, we see clear variegation in terms of how the current conditions of water access, affordability or

\footnotetext{
${ }^{16}$ Work by Wutich and Ragsdale (2008) has similarly highlighted that perceived inequities related to water are crucial factors linked to reported stress among residents in Cochabamba, Bolivia. As they note, it is not simply the social inequities within a distribution system that causes stress, but the clarity, perceived fairness, and predictability of the system. Similarly, in their discussion of the linkages between service delivery and the state Brinkerhoff et al. (2012) emphasize the importance of fair and equitable provision as central for trust in the state. As they conclude: "Even if the State improves service provision, it may fail to improve trust in the State unless users feel benefits are equitably distributed (285)."

17 Our results are perhaps interesting for the considerable number of respondents who agree that water is of good quality, is easy to access, and even the over $60 \%$ who say that they are 'satisfied' in light of ongoing service delivery protests and intense politicization. In light of any critiques that our results are 'too positive,' is noteworthy that our results to generally track similar numbers reported by Booysen, (2007, p 27). Their survey suggests that approximately $58 \%$ of urban South Africans were satisfied with water, electricity and sanitation services. Of interest, white South Africans were the least satisfied of all socio-demographic groups, and Black South Africans were satisfied at the same rate as the national average (58\%), relatively close to our number of $64 \%$.
} 
quality, track against different histories, policies, and everyday sensibilities related to the roles and responsibilities of the state. For South Africa, the human right to water and specific promises for equitable services appears to have been centrally tethered with state legitimacy, or trust, with services (Robins and Redfield, 2016). The absence of such a strong framework around the human right to water, and other factors in Ghana make these connections less apparent. These differences, and the related contextual specificities, open up several interesting questions for consideration related to ongoing debates related to state-society dynamics and the complex politics and interactions related to the human right to water. Adding texture and empirical specificity to some of the openings offered by Angel and Loftus (2018), we agree with the need they highlight to critically think through the role of the state related to the human right to water, particularly, as they note, "to avoid the pitfalls of the South African situation where it appears only the state can dispense water justice (4)." Our evidence lends support to this line of questioning. Yet while we agree that a nuanced perspective is needed we also consider there that remains potential value in assigning responsibility to the state for the delivery of public services - allowing state legitimacy to hinge in part on satisfactory and equitable provision of essential services. 


\section{CONCLUSION: KEY CONSIDERATIONS: LINKING BACK AND MOVING FORWARD}

For the growing literature on political ecologies of the state and infrastructures, our results affirm the importance of resources infrastructures, notably water services, for reconfigurations of state-society dynamics in general, and trust in government in particular - at least in locales (such as in South Africa) where the discourse, practice, and politics associated with the human right to water have taken hold and forged specific expectations. Our multi-sited and multi-method approach also adds needed nuance and specificity to these discussionsparticularly to highlight that these linkages are not necessary, or uniform, but are forged in relation to specific variegated histories and pathways. It is only in light of these differentiated conditions whereby states may or may not be authorized, consolidated, or deemed legitimate in relation to water or other infrastructure (see parallel discussion by Brenner, Peck and Theodore, 2010 on the need to trace geo-institutional variegation for ongoing neoliberalization processes). Applied to the issue of trust and legitimacy of the state, our research affirms conclusions McLouglin, 2015 that such connections are non-linear, and may be conditioned by senses of injustice, or other relational and ideational aspects.

While the linkages we have explored here have been increasingly highlighted in qualitative case study work from multiple contexts in anthropological, geographical, and political ecological literatures (e.g. Meehan, 2014, 2015), quantitative testing of these connections and multi-sited evaluation provides a useful complement. As others have emphasized, quantitative and qualitative approaches can usefully be brought together to uncover and understand complex socio-spatial inequities and aspects of lived experience, including to better understand underlying processes (cf. Sheppard, 2001; Kwan, 2009). Here, the statistical results validate linkages held up in the literature. Nonetheless, the differentiated results between the country contexts, and between different dimensions of water services (access, quality and satisfaction), add nuance and specificity to these discussions. Together, combining insights from qualitative and quantitative studies, and better connecting recent political ecological and allied work with longer standing work on services, trust, and institutions in political science adds specificity and nuance to our understanding of these site specific linkages.

The results here are also suggestive for ongoing debates related to the politics of the human right to water and its uneven implementation (Sultana and Loftus, 2012, Mehta, 2006; Yates and Harris, 2018). While we might be impressed by the overall statistics of improved access associated with the achievement of the MDGs (both in Ghana and South Africa), the work here contributes to a growing appreciation for what else, beyond basic access, might be at stake in considering water services, quality, or relative inequities. Beyond minimal access, the results emphasize the fundamental importance of relative senses equity in relation to uneven access, quality, or satisfaction (Mehta, 2006; Rodina, 2017; Wutich and Ragsdale, 2008). As such, our results echo recent contributions highlighting the need to broaden our approach to water securities, to include broad socio-hydrologic processes, rather than focus on water provision in the strict sense of $\mathrm{H}_{2} \mathrm{O}$ (Jepson et al., 2017). For those pursuing global development goals related to water access, these insights call to question a narrow focus on water delivery as the goal, and 
instead invites attention to the broader context of water services as fundamentally connected to human well-being, equity, or accountability.

In concert with recent contributions of Angel and Loftus (2018) we see value in critically interrogating what it means to center the state in policies and discourses related to the HRW-as they suggest, we might do better to work both 'with and beyond' the state to pursue water justice. ${ }^{18}$ While important to interrogate state-centricity, our results are nonetheless suggestive that satisfaction, quality and notions of equity might be key pathways to hold governmental institutions accountable. As Mehta (2006) notes, there is a need for mechanisms of state accountability, particularly to allow for economic and social rights to be realized for poor and vulnerable populations-an issue she suggests is often missing in human rights debates (64). More fully understanding these connections will inform a stronger appreciation of the difficulties associated with the uneven implementation of the human right to water, implications for water justice, and also what conditions of possibility this opens up for various state forms rooted in complex socio-ecological relations (Angel and Loftus 2018). Taken together, the work here offers a useful combination of methods, a multi-sited study design, and learning from diverse literatures to offer new insights and key questions for further exploration.

\footnotetext{
18 A recent contribution by Bond and Galvin (2019) similarly problematizes the role of the state in the Human right to water and its implementation, aiming for nuance and to capture the ambivalences and tensions inherent in such.
} 


\section{REFERENCES}

Afrobarometer (2016) Trust and corruption in public institutions: Ghanaian opinions Findings from the Afrobarometer Round 6 survey in Ghana. Available at:

http://afrobarometer.org/sites/default/files/mediabriefing/ghana/gha_r6_presentation3 trust_corruption.pdf (accessed 28 November 2016)

Ainuson KG (2010) Ensuring adequate water supply to disadvantaged urban communities in Ghana. African Studies Quarterly 11(4): 59-82.

Alatout S (2008) States of Scarcity: Water, Space, and Identity Politics in Israel, 1948-1959. Environment and Planning D 26(6): 959-982.

Alexander P (2010) Rebellion of the poor: South Africa's service delivery protests - a preliminary analysis. Review of African Political Economy 37(123): 25-40.

Amenga-Etego RN and Grusky S (2005) The New Face of Conditionalities: The World Bank and Water Privatization in Ghana. In: McDonald D and Ruiters G (eds) The Age of Commodity: Water Privatization in Southern Africa. London and Sterling, VA: Earthscan, pp.275-290.

Angel J. and A Loftus (2018) With against and beyond the human right to water. Geoforum, 98: 206-213. DOI: https://doi.org/10.1016/j.geoforum.2017.05.002

Asunka J (2013) What People want from Government: Basic Service Performance Ratings, 34 countries. Report, Afrobarometer.

Bawa Z (2011) Where is the State? How is the State? Accessing Water and the State in Mumbai and Johannesburg. Journal of Asian and African Studies 46(5): 491 - 503.

Bénit-Gbaffou C and Oldfield S (2011) Accessing the state: Everyday practices and politics in cities of the South. Journal of African and Asian Studies 46(5): 445-452.

Bond P and Dugard J (2008) The Case of Johannesburg Water: what really happened at the prepaid parish pump. Law, Democracy and Development, 12(1): 1-28.

Bond P (2012) The Right to the City and the Eco-Social Commoning of Water: Discursive and Political Lessons from South Africa. In:Sultana F and A Loftus (eds) The Right to Water: Politics, Governance and Social Struggles. UK, Earthscan, Taylor and Francis. pp.190-205.

Bond P and M Galvin (2019) Water, Food and Climate Commoning in South African Cities: Contradictions and prospects. In: Vivero-Pol JL, Ferrando T, De Schutter O and Mattei U (eds) Routledge Handbook of Food as a Commons. Routledge, pp.231-248. 
Booysen S (2007) With the ballot and the brick: the politics of attaining service delivery. Progress in Development Studies 7(1): 21-32.

Bridge G (2014) Resource geographies II: The resource-state nexus. Progress in Human Geography 38(1): 118-130.

Brinkerhoff D, Wetterberg A and Dunn S (2012) Service delivery and legitimacy in fragile and conflict-affected states. Public Management Review 14(2): 273-293.

Brenner N, Peck J and Theodore N (2010) Variegated neoliberalization: geographies, modalities, pathways. Global Networks 10(2): 1-41.

Bustamante R, Crespon C and Walnycki A (2012) Seeing through the Concept of Water as a Human Right in Bolivia. In: Sultana F and Loftus A (eds) The Right to Water: Politics, Governance, and Social Struggles. Abingdon, UK: Routledge, pp.223-240

Carpenter S, Slater R and Mallet R (2012) Social protection and basic services in fragile and conflict affected situations. Report, Overseas Development Institute, Secure Livelihoods Research Programme, London, UK, month

Chingwete A (2016) In South Africa, citizens' trust in president, political institutions drops sharply. Report, Afrobarometer Dispatch, May.

Clark C (2017) Of What Use is a Deradicalized Human Right to Water? Human Rights Law Review 17: 231-260.

Dapaah EK and Harris LM (2017) Framing community entitlements to water in Accra, Ghana: A complex reality. Geoforum 82: 26-39.

DWAF(Department of Water Affairs and Forestry) (2008) Water Allocation Reform Strategy (WARS) Available at: https://www.dwa.gov.za/WAR/documents/WARStrategySep08.pdf (accessed 28 October 2015).

Fantini E, Muluneh T and Smit H (2018) Big projects, strong states? Large scale investments in irrigation and state formation in the Beles valley, Ethiopia. In: Menga F and Swygedouw E (eds) Water, technology and the Nation-state. Oxon, UK, New York, NY:Routledge, Earthscan, pp. 65-80.

Guerrero A (2011) Rebuilding Trust in Government via Service Delivery: The case of Medellin, Colombia. Washington DC: World Bank.

Gupta A (1995) Blurred boundaries: The discourses of corruption, the culture of politics, and the imagined state. American Ethnologist 22(2): 375-402. 
Harris L (2012). State as Socio-Natural Effect: Variable and Emergent Geographies of the State in Southeastern Turkey. Comparative Studies of South Asia, Africa and the Middle East 32(1): 25-39.

Hellberg S (2018) The biopolitics of water. Oxon, UK New York, NY: Earthscan Routledge.

Jepson WE, et al. (2017) Advancing Human Capabilities for Water Security: A relational approach. Water Security 2: 1-10.

Kaika M (2006) Dams as symbols of modernization: the urbanization of nature between geographical imagination and materiality. Annals, Association of American Geographers 96(2): 276-301.

Kwan MP (2009) Quantification. In: Smith SJ, Pain R, Marston SA, and Jones III JP (eds) The SAGE Handbook of Social Geographies. London: Sage, pp. 573-585.

Levi M, Sacks A and Tyler T (2009) Conceptualizing legitimacy, measuring legitimating beliefs. American Behavioral Scientist 53(3): 354-375.

Levi M and Stoker L (2000) Political Trust and Trustworthiness. Annual Review of Political Science 3: 475-507.

Loftus A (2006) Reification and the dictatorship of the water meter. Antipode 38(5): 1023-1045.

Loftus A (2018). Political ecology II: Whither the state? Progress in Human Geography. https://doi.org/10.1177/0309132518803421

Mahama A, Anaman K and Osei-Akoto I (2014) Factors influencing householders' access to improved water in low income areas in Accra, Ghana. Water and Health. Water and Health 12(2): 318-331.

McDonald DA and Ruiters G (2005) The Age of Commodity: Water Privatization in Southern Africa. London and Sterling, VA: Earthscan.

McDonald, DA and Smith L (2004). Privatising Cape Town: From Apartheid to Neo-liberalism in the Mother City. Urban Studies: 1461-1484.

McFarlane C and Rutherford J (2008) Political infrastructures: Governing and experiencing the fabric of the city. International Journal of Urban and Regional Research 32(2): 363-374.

McLoughlin C (2015) When does service delivery improve the legitimacy of a Fragile or Conflict Affected State? Governance 28(3): 341-356.

Meehan K (2014) Tool-power: Water infrastructure as wellsprings of state power. Geoforum 57: 215-224. 
Meehan K and Molden O (2015) Political Ecologies of the State. In: Agnew J et al. (eds) The Wiley Blackwell Companion to Political Geography. Chicester, UK: John Wiley \& Sons,pp.438-450.

Mehta L (2006) Do Human Rights Make a Difference to Poor and Vulnerable People? Accountability for the right to water in South Africa. In: Newell PJ and Wheeler J (eds) Rights, Resources and the Politics of Accountability. London: Zed Books, pp.63-78.

Menga F and Swyngedouw E (2018) Water, technology and the Nation-state. Oxon, UK, New York, NY: Routledge, Earthscan.

Migdal J (2001) State in Society: Studying How States and Societies Transform and Constitute One Another. Cambridge, UK: Cambridge University Press.

Miraftab F (2007) Governing Post Apartheid Spatiality: Implementing City Improvement Districts in Cape Town. Antipode 39 (4): 602-626.

Mirosa O and Harris L (2012) The Human Right to Water: Contemporary Challenges and Contours of a Global Debate. Antipode 44(3): 932-949.

Morales M, Harris L and Öberg G (2014) Citizenshit: the right to flush and the urban sanitation imaginary. Environment and Planning A 46(12): 2816-2833

Mosse D (2003) The Rule of Water: Statecraft, Ecology and Collective Action in India. Oxford, UK: Oxford University Press.

Municipal Services Project (2018) Available at: https://www.municipalservicesproject.org/ (accessed 09 March 2019).

Nleya N (2011) Linking service delivery and protest in South Africa: An exploration of evidence from Khayelitsha. Africanus 41(1): 3-14.

Painter J (2006) Prosaic geographies of stateness. Political Geography 25: 752-774.

Peloso M and Morinville C (2014) 'Chasing for water': Everyday practices of water access in peri-urban Ashaiman, Ghana Water Alternatives 7(1): 140-159.

Piper L and Lieres BV (2015) The limits of participatory democracy and the rise of the informal politics of mediated representation in South Africa. Journal of Civil Society 12(3): 314-327.

Redfield P and Robins S (2016) An index of waste: humanitarian design 'dignified living' and the politics of infrastructure in Cape Town. Anthropology Southern Africa 39(2): 145-162.

Roberts B, et al. (2018). Growing Western Cape protests show citizens expect greater accountability The Conversation. Available at: https://theconversation.com/growing- 
western-cape-protests-show-citizens-expect-greater-accountability-96547 (accessed 1 July 2018).

Rodina L. and Harris L (2016) Water Services, Lived Citizenship and Notions of the State in Marginalised Urban Spaces: the case of Khayelitsha, South Africa. Water Alternatives 9 (2): 336-355.

Rodina L (2017) Reflections on Water Ethics and Human Right to Water in Khayelitsha, South Africa. In: Ziegler R and Groenfeldt D (eds) Global Water Ethics - Between Action and Reflections. London, UK: Routledge, pp.167-183.

Rodina, L. (2013). Lived notions of citizenship and the human right to water in Site C, Khayelitsha, Cape Town, South Africa. MA thesis, Institute for Resources, Environment and Sustainability. Vancouver, BC, University of British Columbia.

Rothstein B (2009) Creating political legitimacy: Electoral democracy versus quality of government. American Behavior Scientist 53(3): 311-330.

Republic of South Africa (RSA) (1996) Constitution of the Republic of South Africa (Act 108 of 1996). Available at:

http://www.justice.gov.za/legislation/constitution/SAConstitution-web-eng.pdf (accessed 28 October 2015).

Sahle EN, Galvin M, Pierce B, and Todd K (2019) The UN's Human Right to Water in the Context of New Water Governance Regimes. In: Sahle EN (ed) Human Rights in Africa. Palgrave Macmillan, pp.283-327.

Sheppard E (2001) Quantitative geography: representations, practices, and possibilities Environment and Planning D: Society and Space 19: 535-554.

Sivaramakrishnan K (1999) Modern Forests: Statemaking and Environmental Change in Colonial Eastern India. Stanford, CA, Stanford University Press.

Smith L and Hanson S (2003) Access to water for the urban poor in Cape Town: Where equity meets cost recovery. Urban Studies 40(8): 1517-1548.

Sneddon C (2013) Water, governance and hegemony. In Harris L, Sneddon C, and Goldin J (eds) Water Governance in the Global South: Scarcity, Marketization, and Participation. London: Routledge: pp.13-24.

South Africa Yearbook (2014) Water Affairs, RSA Communications. Available at: http://www.gcis.gov.za/content/resourcecentre/sa-info/yearbook2013-14 (accessed 5 October 2015).

StolerJ, Fink G, Weeks J et al. (2012) When urban taps run dry: Sachet water consumption and health effects in low income neighborhoods of Accra, Ghana. Health and Place 18: 250-262. 
Sultana F and Loftus A (2012) The Right to Water: Politics, Governance and Social Struggles. UK: Earthscan and Taylor and Francis.

Thompson L, Nleya N, et al. (2011) Perceptions of service delivery: Governance and service delivery report for Khayelitsha, Langa and Delft. Report, African Centre for Citizenship and Democracy, University of the Western Cape, Cape Town, South Africa, month.

Times LIVE (2016) 9 Thing you need to know about the \#statecapture report. Available at: http://www.timeslive.co.za/politics/2016/11/02/9-things-you-need-to-know-aboutthe-StateCaptureReport (accessed 2 November 2016).

Whitehead M et al. (2007) The Nature of the State: Excavating the Political Ecologies of the Modern State. Oxford: Oxford University Press.

Wilson J and Pereira T (2012) Water demand management's shadow side: Tackling inequality and scarcity of water provision in Cape Town. EMG Water and Climate Change Research Series. Cape Town, South Africa: Environmental Monitoring Group.

Wutich A and Ragsdale K (2008) Water insecurity and emotional distress: Coping with supply, access, and seasonal variability of water in a Bolivian squatter settlement. Social Science \& Medicine 67: 2116-2125.

WHO \& UNICEF Joint Monitoring Programme for Water Supply and Sanitation (2008) Progress on Drinking Water and Sanitation: Special Focus on Sanitation. Report, World Health Organization, New York and Geneva.

Yates JS and Harris LM (2018) Hybrid regulatory landscapes: The human right to water, variegated neoliberal water governance, and policy transfer in Cape Town, South Africa, and Accra, Ghana. World Development 110: 75-87.

Yeboah I (2006) Subaltern strategies and development practice: Urban water privatization in Ghana. Geographical Journal 172(1): 50-65. 